Kastamonu Eğitim Dergisi
$\begin{aligned} & \text { Kastamonu Education Journal } \\ & \text { kart 2020 Cilt:28 Sayı:2 }\end{aligned}$
kefdergi.kastamonu.edu.tr

\title{
Özgür Düşünme ve Özgüven: Yaratıcı Drama Yöntemiyle Kazandırılabilir mi?
}

\section{Free Thinking and Self Confidence: Can It be Acquired Creative Drama?}

\author{
Şükran CALP ${ }^{1}$
}

Öz

Bu çalışmanın amacı, yaratıcı drama yöntemi kullanılarak gerçekleştirilen etkinlikler yoluyla özgür düşünme ve özgüvenin gelişimine destek olabilecek bir modeli deneyimlemek ve uygulamalardan sonra söz konusu iki değerle ilgili katılımcıların değişimlerini kendi izlenimleriyle belirlemektir. Araştırmanın çalışma grubu, Türkiye'deki bir devlet üniversitesinin Eğitim Fakültesi, Sınıf Eğitimi Anabilim Dalında 2017-2018 yılında 3. sınıfta eğitim gören 23 öğretmen adayından oluşmaktadır. Bu çalışma için özgüven ve özgür düşünme değerleriyle ilgili üçer, toplamda 6 haftalık drama atölyesi hazırlanıp uygulanmıştır. Bulgular, özgüvenin "bilgi sahibi olma, kendini ayarlama, etkili iletişim, birey olma sorumluluğu, kendini keşfetme, girişimcilik ve duygu kontrolü" kavramlarılla ilişkili olduğunu göstermektedir. Özgür düşünme ise, "farklılıklara saygı, özgünlük, kalıp yargılardan kurtulma, sanatla ilgilenme ve zihinsel gelişim" ile ilişkili bulunmuştur. Ayrıca yaratıcı dramanın, özgür düşünme ve özgüven değerlerinin kazandırılmasında kullanılabilecek bir yöntem olduğu görülmüştür.

Anahtar Kelimeler: Özgüven, özgür düşünme, bağımsız düşünme, özerklik, bireysel değer, yaratıcı drama

\section{Abstract}

The aim of this study is to experience a model that can support the development of free thinking and selfconfidence of pre-service teachers through creative drama and to determine the changes of pre-service teachers about these two values with their own impressions after the practices. The study group consisted of 23 pre-service teachers studying in the 3rd grade in the Department of Primary School from Turkey Teaching in 2017-2018. In accordance with the aim of the study, three 6-week drama workshops were applied on self-confidence and free thinking values. According to the findings, self-confidence is related to "having knowledge, self-regulation, effective communication, responsibility for being an individual, self-discovery, entrepreneurship and emotion control". Free thinking, on the other hand, is related to "respect for differences, originality, getting rid of stereotypes, dealing with art and mental development." In addition, drama is thought to be a method that can be used to gain values of free thinking and self confidence.

Keywords: Self-confidence, free thinking, independent thinking, autonomy, individual value, creative drama

${ }^{1}$ Erzincan Binali Yıldırım Üniversitesi, Eğitim Fakültesi, Temel Eğitim Bölümü, Sınıf Eğitimi ABD, Erzincan, Türkiye, https://orcid.org/0000-0001-6297-9056 Atıf / Citation: Calp, Ş. (2020). Özgür düşünme ve özgüven: Yaratıcı drama yöntemiyle kazandırılabilir mi? Kastamonu Education Journal, $28(2), 1026-1043$. doi:10.24106/kefdergi.702942 


\section{Extended Abstract}

Introduction: This study focuses on "self-direction (independence in thought and action)" and "self-confidence which is defined as being creative, being curious, being free, choosing your own goals and behaviors, being independent". Mental autonomy also creates self-confidence, self-confidence also brings about free thinking. Because an individual who can be original and think freely learns to trust himself. Confident and believing individual can develop more creative and original ideas. For this, a nonrandom, planned education approach is needed. Teaching methods arranged to encourage reasoning, which is a special form of thinking, improves students' creativity. The individual who develops creativity has many reasons to think freely and to be confident. From this point of view, it is thought that creative drama workshops will offer participants an atmosphere that supports autonomy, as it is a method that emphasizes social interaction and originality. The aim of this study is to experience a model that can support the development of free thinking and self-confidence of pre-service teachers through creative drama and to determine the changes of pre-service teachers about these two values with their own impressions after the practices.

Method: The study group consisted of 23 pre-service teachers studying in the 3rd grade in the Department of Primary School from Turkey in 2017-2018. In accordance with the aim of the study, three 6-week drama workshops were planned on selfconfidence and free thinking values. Each workshop lasted approximately 90 minutes. The average age of the study group was 20 and the overall academic average of all students was 2.5 and above in the 4-point system. Four of the students live with their families, 14 live in state dormitories and 5 live in private dormitories, and the whole group defines their economic status as "medium" and "low". Meetings were held with the students identified about 2 months before the 6-week practice and the training to be given to them was explained. One month later, the first face-to-face interviews were conducted to determine the status of free thinking and self-confidence. One month after the first interviews, the actual practices started. During the 1-month period from the first interview to the beginning of "self-confidence and free thinking" practices, 4 preparatory workshops on "Recognition, Meeting and Communication" were applied. In this way, it was ensured that the students were aware of the practice steps of the method to be applied and had pre-entry behaviors.

Findings: Findings show that pre-service teachers had positive thoughts at the beginning of self-confidence but they felt obstacles at the point of free thinking. After the workshops, teacher trainees expressed their positive beliefs about what they could achieve when they trusted them. According to the findings, self-confidence is related to "having knowledge, self-regulation, effective communication, responsibility for being an individual, self-discovery, entrepreneurship and emotion control". All of the students mentioned that there was a positive development in themselves regarding self-confidence and their thoughts on the subject were gathered in 9 categories. These categories are: "Getting rid of crowded phobia", "gaining entrepreneurship features", "learning to participate actively in life", "discovering yourself and your own abilities", "learning social relations and effective ways of communication", "self-adjustment", "having knowledge", "feeling comfortable", "learning about emotion control". Free thinking, on the other hand, is related to "respect for differences, originality, getting rid of stereotypes, dealing with art and mental development." In addition, drama is thought to be a method that can be used to gain values of free thinking and self-confidence.

Resuld and Discussion: Based on all these findings, it was observed that the education given with creative drama method created awareness among the participants that values could be gained with this method. "Creative drama itself is highly effective in developing self-confidence and creativity, even though issues of trust and free thinking are not specifically addressed; this effect is further enhanced when the workshop is specifically about self-confidence and free thinking". Pre-service teachers emphasized that after the workshops, their beliefs about what they could accomplish when they were confident changed positively and expressed that they enjoyed the workshops even though it was difficult to work with abstract concepts. Participants who confused free thinking with the concept of freedom of expression or perceived it as a political phenomenon had information about what it really is and stated that they would try to improve themselves in this way. The participants also noted that in an environment where everyone was almost forced to be the same as others, they realized that it was difficult but very meaningful to remain as yourself. Considering the importance of ensuring that students are self-confident, systematic, entrepreneurial, planned working habits and critical perspective, and developed aesthetic feelings and creativity, "independent and free thinking" and "selfconfidence" values are very important for teachers, teacher candidates and students. two concepts. 


\section{Giriş}

Önemli sosyal denetim mekanizmalarından biri olan değerler, toplumsal bütünlüğün ayrılmaz unsurlarındandır ve sosyal hayatın düzenleyicisidir. Bireyler toplumsal kurallar, gelenekler ve görenekler yoluyla "iyi ile kötü”yü ya da "doğru ile yanlış"ı ayırmayı ve kendi ahlâk ilkeleri doğrultusunda bir ölçü belirlemeyi öğrenir. Elde edilen bu ölçü "değer" adı verilen ilke, izlenim ve inançlar bütününü oluşturur.

Rokeach (1973) değer sınıflamasında amaç(terminal) değer, Schwartz $(1992,1994,2012)$ değer sınıflamasında bireysel değer olarak adlandırılan "öz yönelim” değeri, "yaratıcı olmak, merak duyabilmek, kendine saygısı olmak, özgür düşünceye sahip olmak, eylemde bağımsız olmak, bağımsız karar vermek, kendi amaç ve davranışlarını seçebilmek" şeklinde tanımlanmaktadır. İnsan özgür bir varlıktır ve bu özgürlük ona kendini belirleme ya da tanımlama sorumluluğu yükler. Varoluşçu felsefe, bireyi kendi kimliğini belirleme konusunda teşvik eder (Gutek, 2001). Deci ve Ryan (1985), bir eylem sadece özerk olarak deneyimlendiğinde içsel motivasyonun işler durumda olduğunu; kontroller ve takviye destekler altında bunun işlemesinin intimal dışı olduğunu öne sürmektedir. Özerklik ya da özgür düşünme, bir eylemi tümüyle istemek, seçmek ve kişisel onay almak anlamında kullanılır. İnsanoğlu, içsel ya da dışsal bir baskı hissetmeden, bağımsız olarak bir deneyim yaşama beklentisi içindedir (Schiefele, 2001). Bu beklenti doyurulduğunda "kendine inanma, güvenme" olarak tanımlan özgüven gelişmektedir. Yani bu iki kavram birbiriyle ilişkili görülmektedir.

Bağımsız ve özgür düşünme, kişinin kendi oluşturduğu kurallara göre özgün biçimde akıl yürütmesi, fikir üretmesidir. Başkalarının oluşturduğu değerleri olduğu gibi kabul etmek yerine onları kendi süzgecinden geçirip değerlendirmesi fakat bunu yaparken kendi kadar başkalarını da dikkate almasıdır. Özgür düşünme, dışardan empoze edilen sınırlandırmalara kendini küçük düşürecek düzeyde boyun eğmeye karşı çıkar. Tecrübe edilen yaşantı, dışarıdan değil içeriden yönlendirilen yeni bir bilişsel yapıyı doğurur. Bilişsel gelişim özerktir. Özerk olarak elde edilen öğrenme, ileri düzeyde kavrama ve anlamayı sağlar (Piaget 1967). Piaget'nin kuramında en etkin ve iyi uyum sağlamış yapı, kontrol mekanizması özgün ve kendi kendine işlediğinde ortaya çıkar. Bir başka ifadeyle bilişsel gelişim süreci kişi, öz düzenleyici ve özerk olup kendi kendini yönetebildiğinde en doğal şekilde işler (Kamii ve Ewing, 1996).

İnsanların, öz benlikleriyle bir davranışta bulunma ihtiyacı ve bu davranışların başlatılması ya da sona erdirilmesiyle ilgili kararları verirken iradesini kullanması "özerklik" olarak ifade edilir. Öz-belirleme kuramına göre özerklik, kişinin iradesini kullanarak davranışlarını düzenleyebilmesidir (Deci ve Ryan, 2000). Özerklik, çocukların istediklerini yapmalarına veya öğretmenin kontrolünden çıkmalarına müsaade etmek demek değildir. Tam aksine; öz düzenlemeyi, kendini kontrol etmeyi etkili ve sorumlu bir şekilde yönlendirmeyi öğrenmektir.

Piaget'e göre zihinsel özerklik bilişsel ve duyuşsal özerklik olmak üzere iki ögeden oluşur. Çocuklar için de yetişkinler için de bilişsel gelişimi destekleyen, "duyuşsal gelişim"dir. Zihnin ne tür konulara odaklanacağını duyuşsal yapı belirler. Duyuş, duyguları, ilgileri, istekleri, eğilimleri, değerleri ve genel olarak hisleri içerir. Duyuşsal özerklik ise, hem başkaları hem kendisi için adil ve dürüst olmaya, doğru olanı yapmaya yönlendirir. Kişinin yapılandırılmış değerlerini ve iradenin oluşumuyla ortaya çıkan bu değerlere göre davranma duygusunu birleştirir, öz disiplin oluşturur (Devries, 1999). Duyuşsal özerklik bir anlamda öz disiplinin temelidir. Çünkü böyle bir özerklik, kişinin yapılandırılmış değerler ve bu değerlere bağlı kalma zorunluluğuna dayanan davranış seçimine yol gösterir. Duyuşsal özerklik, özgür bir şekilde seçilen işbirliğine dayanır (Wadsworth, 2015).

Hem bilişsel hem de duyuşsal ögelerden oluşan zihinsel özerklik, kişinin kendisi adına seçimler yapması ve nasıl karar vereceğini öğrenmesi ile ilişkilidir. Kişinin, bilgiye ulaşmak için kendi dengesizliğini takip ederek soruşturması, öne çıkanların peşinden gitmesi, hipotezleri test etmesi ve şu an bilinene dayanarak daha sonra ne yapılacağına karar vermesi bir başka ifadeyle kendi eylem sürecini ortaya çıkarması zihinsel özerkliğin göstergeleridir (Devries, 1997).

Zihinsel özerklik, bireylerin problem çözücüler olarak en etkili öğrenme ve gelişim yollarını nasıl bulacaklarını öğrenmelerinde önemlidir. Bu, “öğrenmeyi öğrenme”nin nasıl gerçekleştirileceğiyle yakından ilgilidir. Öğrencinin hipotez kurma, mantıksal çıkarımlar yapma, soru sorma, hayal etme, zihinde canlandırma, sorgulama, araştırma ve keşfetme deneyimleri yaşamasına izin verilmelidir (O'Loughlin, 1992). Gelişmiş özerk öğrenme alışkanlığı ya da özgür düşünme, problem çözme için söz konusu bilişsel bilgiden daha önemlidir. Herhangi bir bilgiden yoksun özerk öğrenci o bilgiyi nasıl edineceğini bilir. Fakat özerklik, irade ya da istek yoksa gerekli bilişsel bilgiye sahip olmak o kadar kolay olmayabilir (Wadsworth, 2015).

Piaget'nin bakış açısına göre, yapılandırmacı yöntemin temellendirildiği, keşfetmenin ve bilgi inşa etmenin değer görüp desteklendiği ve özerkliğin teşvik edildiği çevrelerde, problem çözme becerisi gelişir (Kamii ve Ewing, 1996). Problem çözme, sistematik yollarla geliştirilmiş akıl yürütmeyi gerektirir ve gerçekte özerk bir iştir. Öte yandan özerklik 
de, problem çözme isteğini ve başarı sağlanabileceği inancını gerektirir. Kişinin kendine inanması birçok zihinsel işlemi olumlu etkiler. Bu yüzden bilişsel gereklilikler gibi duyuşsal şartlar da etkin problem çözme için önemlidir.

Tüm bu açıklamalar ışı̆ıında denilebilir ki zihinsel özerklik aynı zamanda kendine güveni oluşturur, kendine güven de özgür düşünmeyi tetikler. Çünkü özgün olabilen, özgür düşünebilen birey, kendine güvenmeyi öğrenir. Kendine güvenen ve inanan birey, daha yaratıcı ve özgün fikirler geliştirebilir. Bu nitelikler yapılandırılmamış ya da transfer edilmeyen bilgi yüklü pasif eğitim uygulamalarıyla değil, derin anlayış, kişisel özerk yapı ve özgüveni besleyen uygulamalarla en iyi şekilde öğrenilir. Bunun için her şeyden önce tesadüfî olmayan, planlı bir eğitim anlayışına ihtiyaç duyulmaktadır. Düşünmenin özel bir şekli olan akıl yürütmeyi teşvik eder şekilde düzenlenmiş öğretim yöntemleri, öğrencilerin yaratıcılığını geliştirir. Yaratııılığı gelişen birey, hem özgür düşünebilir hem de kendine güvenmek için birçok sebebe sahiptir. Bu açıdan bakıldığında sosyal etkileşim ve özgünlüğü ön plana çıkaran bir yöntem olması dolayısıyla yaratıcı drama atölyelerinin², katılımcılara özerkliği destekleyici bir atmosfer sunacağı düşünülmektedir.

Yaratıcı drama katılımcılarına, harekete geçme ve hayal etme fırsatı sunan, insanların gerçek hayatta deneyimleyebileceklerini yansıtması için yönlendiren, doğaçlama ve süreç merkezli bir disiplindir (Guli, 2004). Drama, yaratıcı ve eleştirel düşünme dahil olmak üzere farklı düşünce türlerini kullanmayı ve geliştirmeyi hedefler. Aynı zamanda özgün düşünme ile işbirlikli düşünmeyi içerir (Baldwin, 2009).

Yaratıcı drama, zihinsel becerilerin ve kişilik özelliklerinin geliştirilmesinde önemli bir yol olması yönüyle dikkat çekicidir. Yaratıcı dramadaki etkinliklerin, katılanların düşünceleri ve dağarcıkları ekseninde şekillenmesi, dramanın insanların duygu ve düşüncelerine değer verdiğinin bir göstergesidir. Drama bireye, hareketlerin, duyuların, dilin, düşüncenin, iletişim ve duyguların bir araya getirildiği bir sentez sunmaktadır. Dramadaki yaratıcı süreçlerin sonunda kişi, içinde saklı kalmış yeteneklerini keşfeder, kendini tanır, en verimli, mutlu, zevkle çalışabileceği, kendine ve topluma faydalı olabileceği, doğru ve sağlıklı kararlar alabileceği alanı seçer. Böylelikle öz güveni gelişmiş, başkalarıyla çalışabilme düsturunu kazanmış, demokratik ve çağdaş bir insan haline gelir. Bu çalışma kapsamında, bireyi aktif kılması, mümkün olduğunca özgür bir ortam oluşturması ve özgünlüğü teşvik etmesi yönüyle yaratıcı drama, alternatif bir yol olarak düşünülmüştür.

\section{Çalışmanın Amacı}

Bu çalışmanın amacı, yaratıcı drama yöntemi kullanılarak gerçekleştirilen etkinlikler yoluyla özgür düşünme ve özgüvenin gelişimine destek olabilecek bir modeli deneyimlemek ve uygulamalardan sonra söz konusu iki değerle ilgili katılımcılarda ortaya çıkan değişiklikleri belirlemektir.

\section{Yöntem}

Nitel araştırma yönteminin kullanıldığı bu çalışma, öğrencilerin "özgür düşünme" ve "özgüven" değerleri ve bu değerlerin eğitimine ilişkin düşüncelerini araştırmak üzere betimleyici bir yaklaşım izlenerek yürütülmekle beraber 6 haftalık uygulama sürecini de barındırmaktadır. Bu yönüyle eylem araştırması mahiyetindedir. Eylem araştırması, bir grup veya kişi tarafından yürütülen çözüm yönelimli bir araştırma olup (Beverly, 1993), doğrudan katılım yoluyla bireylerin güçlenmesini, işbirliğini ve sosyal değişmeyi beraberinde getirmektedir. Bir başka tanımda eylem araştırması, bir grup insanın bir problemi tanımlaması, problemi çözmek için çabalaması, çabalarının ne kadar başarılı olduğunu görmesi, eğer sonuçtan tatmin olmazlarsa yeniden denemesi kısaca, yaparak ve yaşayarak öğrenmesidir (O'Brien, 2001)

\section{Çalışma Grubu}

Araştırmanın çalışma grubu, 2017-2018 eğitim yılında Türkiye' deki bir devlet üniversitesinin Eğitim Fakültesi, Sınıf Eğitimi Anabilim Dalında okuyan 15'i kadın, 8'i erkek olmak üzere toplam 23 kişilik 3. sınıf öğrencileridir. Söz konusu çalışma grubu, öğretim elemanının Sınıf Eğitimi Anabilim Dalında okutmakta olduğu Drama dersinin öğrencileridir. Dolayısıyla kolay ulaşılabilir örneklem tercih edilmiştir.

Çalışma grubunun yaş ortalaması 20 olup öğrencilerin tamamının genel akademik ortalaması 4'lük sistemde 2.5 ve üzerindedir. Öğrencilerin 4'ü ailesiyle beraber, $14^{\prime}$ ü devlet yurdunda, 5'i de özel yurtlarda kalmaktadır ve katılımcıların tamamı, ekonomik durumunu "orta" ve "düşük" düzey olarak tanımlamıştır.

\footnotetext{
2 Drama atölyesi, "hazırlık ve ısınma, canlandırma ve değerlendirme" şeklinde 3 bölümden oluşan bir ders planıdır. Bu çalışma içinde sık sık kullanılan atölye ifadesi, belli kazanımlara göre şekillenmiş etkinliklerin bütünü anlamında kullanılmaktadır.
} 


\section{Veri Toplama Süreci}

6 haftalık özgür düşünme ve özgüven atölyelerinden önce belirlenen öğrencilerle topluca toplantı yapılmıştır ve onlara verilecek eğitim anlatılmışır. 1 ay sonra özgür düşünme ve özgüven durumlarını tespit etmeye ilişkin ilk yüz yüze görüşmeler gerçekleştirilmiştir. Görüşmeler sırasında araştırmacı tarafından hazırlanan "görüşme formu" kullanılmıştır. Uygulama öncesi ve sonrasındaki görüşmeler ortalama 40 dakika sürmüştür.

Görüşmelerde ilk önce öğrencilerin özgüven ve özgür düşünme değerlerine ilişkin nasıl bir potansiyele sahip oldukları, kendilerini nasıl gördükleri belirlenmeye çalışımıştır. Bu amaçla "Kendinize güvenir misiniz? Hangi konularda güvenirsiniz?", "Kendinizi güçlü ya da zayıf yanlarınızla nasıl tanımlarsınız?", "Belirlediğiniz amaçları gerçekleştirme noktasında başarılı olacağınıza inanır mısınız?", "Yeteneklerinizin farkında mısınız?", "Özgür düşünmeyi nasıl tanımlarsınız?", "Özgür kararlar verdiğinizi düşünüyor musunuz?”, "Özgür düşünceye sahip misiniz?", "Özgür düşünmeyi gerçekleştirebildiğinize inanıyor musunuz?" soruları sorulmuştur. İkinci olarak öğretmenlik mesleğini icra ederken bu iki değeri kazandırmak için yaratıcı drama yöntemini kullanıp kullanmayacaklarına ilişkin düşünceleri sorgulanmıştır. Atölyelerin bitiminde öğrencilerdeki özgüven ve özgür düşünmeye yönelik değişiklik sorgulanmıştır.

İlk görüşmelerden 1 ay sonra asıl uygulamalar başlamıştır. İlk görüşmeden "özgüven ve özgür düşünme" uygulamalarının başlamasına kadar geçen 1 aylık süreçte "Tanıma, Tanışma ve illetişim ve Oyun" konulu 4 hazırlık atölyesi gerçekleştirilmiştir. Böylelikle öğrencilerin uygulanacak yöntemin uygulama basamaklarını fark ederek hazırlanması ve ön giriş davranışlara sahip olması sağlanmıştır. Şekil 1'de araştırmanın aşamaları yer almaktadır.

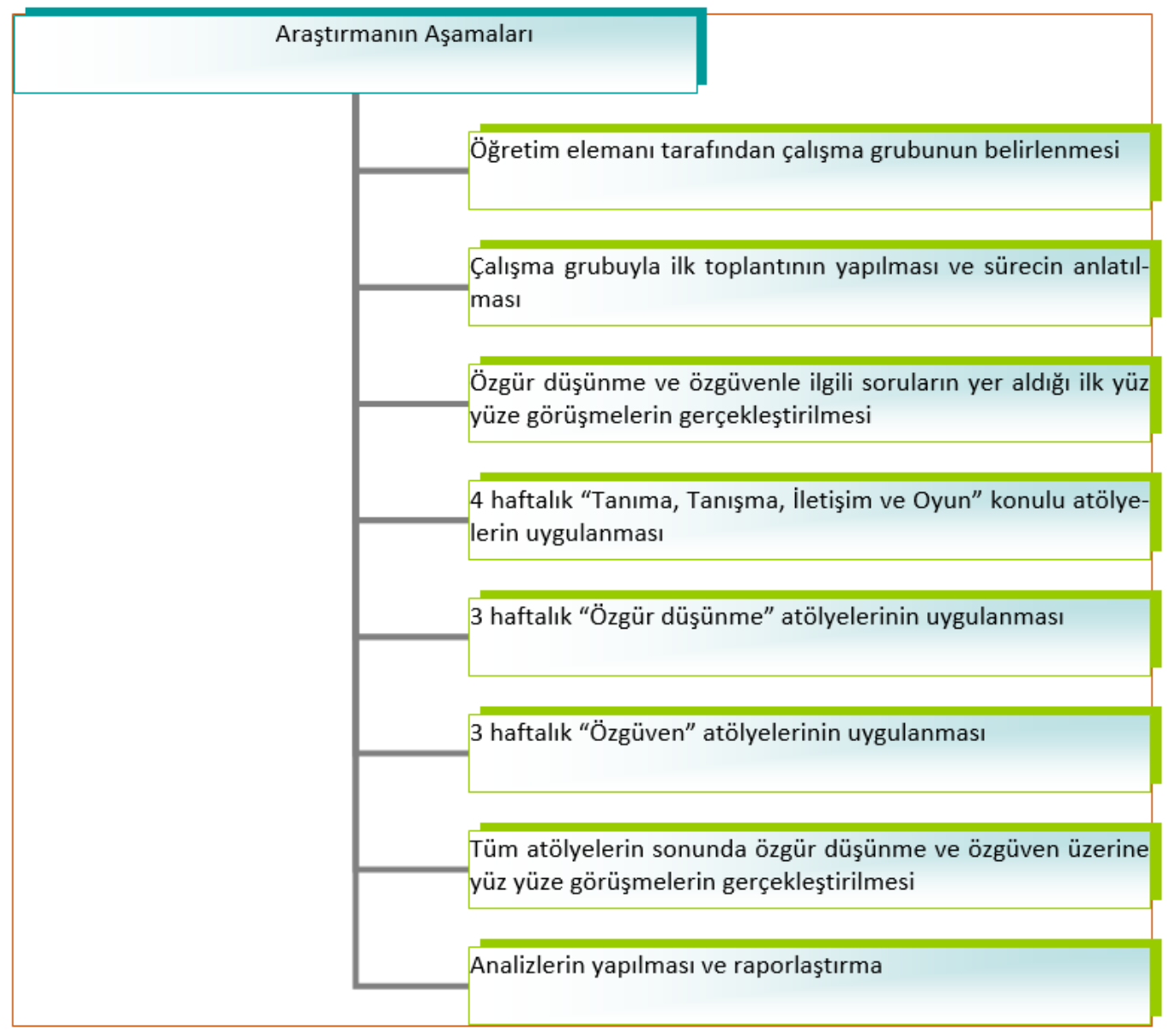

Şekil 1. Uygulama basamakları ve araştırma süreci

Çalışmanın amacına uygun olarak özgüven ve özgür düşünme değerleriyle ilgili üçer, toplamda 6 haftalık drama atölyesi planlanmış ve uygulanmıştır. Her bir atölye, yaklaşık 90 dakika sürmüştür. Aşağıda atölyelere ilişkin kazanım, araç-gereç ve içerik bilgilerine yer verilmiştir.

Birinci özgüven atölyesi: "Kendini tanır ve tanıtır." "Yeteneklerini tanımlar.", "Hayattaki başarılarını ifade eder." ve "Her bireyin değerli olduğunu bilir." kazanımları doğrultusunda şekillenmiştir. Rol oynama, soru-cevap, sıcak sandalye ve bilinç koridoru teknikleri kullanılarak toplam 8 etkinlik oluşturulmuştur. Kalem, kağıt, çeşitli objeler, başarılı ve ünlü insanların hayat hikayeleri ve Athena'nın “Ben Böyleyim” isimli parçası, atölyede kullanılan araçlardır. 
İkinci özgüven atölyesi: “Cesaretle karar vermenin önemini anlar.", "Hayattaki başarılarını ifade eder." ve "Duygu ve düşüncelerini etrafındakilerle paylaşır." kazanımları doğrultusunda şekillenmiştir. Rol oynama, soru-cevap, fotoğraf karesi ve rol kartları teknikleri kullanılarak toplam 6 etkinlik oluşturulmuştur. Kalem, kağıt, çeşitli fotoğraf ve objeler, atölyede kullanılan araçlardır.

Üçüncü özgüven atölyesi: "Özgüven duymanın önemini anlar." ve "Güçlü ve güçsüz yanlarını ifade eder." kazanımları doğrultusunda şekillenmiştir. Rol oynama, soru-cevap ve donuk imge teknikleri kullanılarak toplam 7 etkinlik oluşturulmuştur. Boya kalemi, çeşitli boyutlarda resim kağıdı, Kitaro'nun "Silk Road" isimli parçası, "Kendine Güvenen Kurbağa" isimli hikaye ve çeşitli özlü sözler atölyede kullanılan araçlardır.

Birinci özgür düşünme atölyesi: "Bilgi sahibi olmanın önemini anlar." ve "Kanıksanmış görüşlerden ve önyargılardan sıyrılmanın önemini anlar." kazanımları doğrultusunda şekillenmiştir. Rol oynama, soru-cevap, sıcak sandalye, bilinç koridoru ve donuk imge teknikleri kullanılarak toplam 8 etkinlik oluşturulmuştur. Kalem, kağıt, renkli balonlar, 2 oyun topu ve Nil Karaibrahimgil'in "Ben Özgürüm" isimli parçası, atölyede kullanılan araçlardır.

íkinci özgür düşünme atölyesi: "Düşünce üretir.", "Karşılaştığı problemlere yaratıcı çözüm yolları üretir." ve "Sorgular ve mantıksal çıkarımlar yapar." kazanımları doğrultusunda şekillenmiştir. Rol oynama, soru-cevap, dedikodu halkası, beyin fırtınası, liderin role girmesi ve fotoğraf karesi teknikleri kullanılarak toplam 8 etkinlik oluşturulmuştur. Kalem, kağıt, çeşitli fotoğraflar, yün yumağı ve 2 oyun topu, atölyede kullanılan araçlardır.

Üçüncü özgür düşünme atölyesi: "Kendi davranışının sorumluluğunu üstlenmenin gerekliliğini bilir." ve "Kendi gibi olmanın değerini anlar." kazanımları doğrultusunda şekillenmiştir. Rol oynama, soru-cevap bölünmüş ekran ve donuk imge teknikleri kullanılarak toplam 8 etkinlik oluşturulmuştur. Kalem, kağıt, 3 metrelik ip halat ve Tarkan'ın “Başkası Olma Kendin Ol" isimli parçası atölyede kullanılan araçlardır.

Drama atölyelerinde;

- Öğrencilerin kendi bilgileri, davranışları ve hisleri üzerine odaklanıımıştır.

- Sık sık duygu ve düşünceleri sorgulanmıştır.

- Özlü sözler ve edebi eserlerden alıntılar kullanılmıştır.

- Bazı canlandırmalar için ahlaki muhakeme yaklaşımı işe koşulmuştur.

- İçtenlik ve doğallık teşvik edilmiştir.

- Öğrencilerin her seferinde farklı kişilerle işbirliği yapması sağlanmıştır.

- Atölyelerin sonunda öğrencilerden yazılı ve sözlü değerlendirme alınmıştır.

- Her atölye, katılımcıların ihtiyaçlarına göre yeniden şekillenmiştir.

Araştırmanın verilerinin çözümlenmesinde içerik analizi tekniği kullanılmıştır. Görüşülen bireylerin düşüncelerini çarpıcı bir biçimde yansıtmak için doğrudan alıntılara yer verilmiştir. Görüşme verileri bir alan uzmanı tarafından incelenerek birbirinden bağımsız olacak biçimde kodlar ve temalar oluşturulmuştur.

\section{Veri Analizi, Geçerlik ve Güvenirlik}

Araştırmada kullanılan yaratııı drama atölyeleri araştırmacı tarafından hazırlanmış ve atölye kazanımları literatür incelenerek oluşturulmuştur. Oluşturulan drama atölyeleri, drama eğitiminde uzman bir akademisyen ile Eğitim Psikolojisi dersini okutan bir akademisyen tarafından incelenmiştir. Alınan görüşler doğrultusunda atölyelere son şekli verilmiştir. Uygulanan her atölyede karşılaşılan aksaklıklar, eylem araştırmasının doğası gereği bir sonraki atölyede düzeltilmiştir. Elde edilen kodların ve temaların güvenirliğini ortaya çıkarmak için Miles ve Huberman'ın (1994), önerdiği "uyum yüzdesi" formülü kullanılarak güvenirlik değeri hesaplanmıştır. Uyum yüzdesi= (Uzlaşma) / (Uzlaşma + Uzlaşmama) X 100 biçiminde formüle edilmektedir. Buna göre araştırmalardaki uyum yüzdesinin 70 ve üstü olması durumlarında görüşme verilerinin kullanılabileceği belirtilmektedir (Yıldırım ve Şimşek, 2000). Bu araştırma için uyum yüzdesi 76 bulunmuştur. Görüşme yoluyla elde edilen veriler nitel araştırma tekniklerine uygun olarak öncelikle yazıya aktarılmış, daha sonra içerik analizi yapılmıştır. İçerik analizinde temel amaç, toplanan verileri açıklayabilecek kavramlara ve ilişkilere ulaşmaktır. Betimsel analizde özetlenen ve yorumlanan veriler, içerik analizinde daha derin bir işleme tabi tutulur ve betimsel bir yaklaşımla fark edilemeyen kavram ve temalar içerik analizi sonucu keşfedilebilir. Bu amaçla toplanan verilerin önce kavramsallaştırılması, daha sonra da ortaya çıkan kavramlara göre mantıklı bir biçimde düzenlenmesi ve buna göre veriyi açıklayan temaların saptanması gerekmektedir (Yıldııım ve Şimşek, 2000). 


\section{Bulgular}

Bulgular drama yönteminin kullanıldığı atölyelerden önce ve sonra olmak üzere iki başlıkta sunulmuştur. Atölyelerden önce elde edilen veriler için kod ve kategoriler oluşturma yoluna gidilmemiş, bulgular öğrencileri genel mahiyette tanımlayııı bir üslupla sunulmuştur.

\section{Atölyelerden Önceki Düşüncelere iliş̧in Bulgular}

İlk görüşmeler, öğrencilerin öz güvene sahip olma noktasında olumlu düşüncelere sahip olduğunu ancak özgür karar verme noktasında engellemeler hissettiğini göstermektedir.

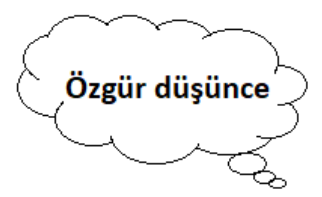

.Özgür düşünmem kısıtlanıyor.

. Özgür düşünce, siyasi bir eylemdir.

. Özgür düşünebilmek yaratııılık gerektirir.

. Özgür düşündüğümde özgür olabilirim.

. Özgür olmak için en büyük engel kendimim.
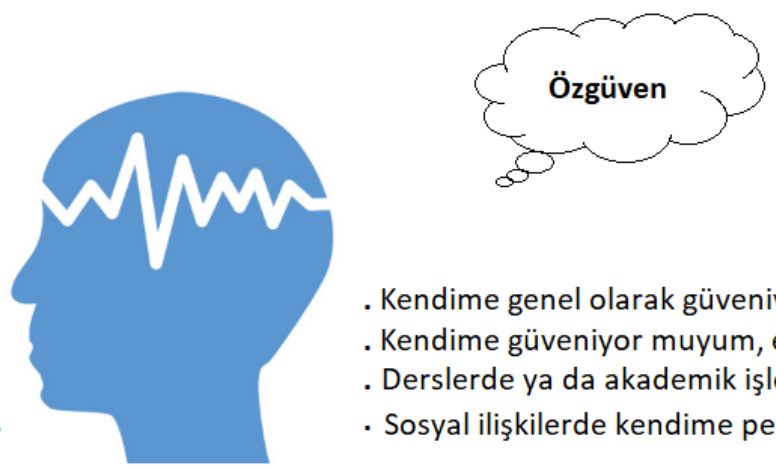

. Kendime genel olarak güveniyorum.

. Kendime güveniyor muyum, emin değilim.

. Derslerde ya da akademik işlerde iyiyim.

- Sosyal ilişkilerde kendime pek güvenmem.

\section{Şekil 2. Uygulama öncesi görüşülen öğrencilerin kullandığı bazı cümleler}

23 öğrencinin 19’u kendine genel anlamda güvendiğini, inandığını ifade etmiştir. 4 öğrenci akademik konularda güvendiğini, fakat insan ilişkileri noktasında güvensizlik yaşadığını ifade etmiştir. Öğrencilerin 20'si güçlü yönlerini tarif etmiş, zayıf yönlerini anlatmaktan çekinmiştir. 3 öğrenci ise çok da güçlü bir özelliği olmadığını düşündüğünü ifade etmiştir. Öğrenciler zaman zaman kararsızlık yaşasa da genel olarak yeteneklerinin farkında olduğunu belirtmiş ve kendilerini tanıtabilmiştir.

Öğrencilerin tamamı özgür düşünceye sahip olmak noktasında kısıtlamalar hissettiği için bu yetilerinin zamanla köreldiğini ifade etmiştir. Öğrencilere göre kısıtlamalar bazen kendilerinden kaynaklı sebepler olurken bazen de dış etkenler böyle hissetmelerine sebep olmaktadır. Öğrencilerin $18^{\prime}$ i özgür düşünmeyi siyasi konularla ilişkilendirmiştir. Sadece 5 öğrenci bu değere ilişkin "yaratıcı olmak, kendi amaç ve davranışlarını seçebilmek, davranışının sorumluluğunu üstlenmek, bağımsız olmak" anahtar kelimelerini kullanarak tanımlamalar yapmıştır.

23 öğrencinin 22'si yaratıcı drama yöntemiyle değer kazandırma fikrine olumlu bakmış, ancak bunun nasıl olabileceğiyle ilgili fikir üretememiştir. 1 öğrenci konuyla ilgili kafasında hiçbirşey şekillenmediğini vurgulamıştır. 23 öğrencinin tamamı yaratıcı drama yöntemiyle değer öğretimi gerçekleştirip gerçekleştirmeyecekleri sorusuna "Nasıl yapılacağını bilirsem, denerim. Ama hiçbir fikrim yok." şeklinde cevap vermiştir.

\section{Atölyelerden Sonraki Düşüncelere Iilişkin Bulgular}

Atölyelerden sonra öğrencilere özgüvenleri ve özgür düşünmeleriyle ilgili değişiklik olup olmadığı, drama yöntemini bu iki değerin öğretiminde kullanıp kullanmayacakları sorulmuştur.

\section{Özgüvene ilişskin Bulgular}

Öğrencilerin tamamı, özgüvenle ilgili kendilerinde olumlu yönde gelişim olduğundan bahsetmiştir ve konuyla ilgili düşünceleri, 9 kategoride toplanmıştır. Bu kategoriler Şekil 3'te görülmektedir: "Kalabalık fobisini yenme", "girişimcilik özellikleri kazanma", "hayata aktif olarak katılmayı ve paydaş olmayı öğrenme", "kendini ve yeteneklerini keşfetme, kendi olmaktan korkmama", "iyileşmiş sosyal ilişkiler ve etkili iletişim yollarını öğrenme", "kendini ayarlamayı öğrenme", "bilgi sahibi olma", "rahat hissetme, rahat konuşma", "duygu kontrolünü öğrenme".

$\mathrm{K} 1, \mathrm{~K} 2, \mathrm{~K} 5, \mathrm{~K} 6, \mathrm{~K} 8, \mathrm{~K} 9, \mathrm{E} 1, \mathrm{E2}$, E6, E8 kod isimli öğrenciler, iyileşmiş sosyal ilişkiler ve etkili iletişim yollarını öğrenmenin, kendilerine güven duymalarını sağladığını anlatmıştır. Bu katılımcılar insanları tanımak için çaba sarf etmeleri gerektiğini ve bu yolla sosyal ilişkiler iyileşince daha özgüvenli olduklarını düşünmektedir. Aşağıda bu katılımcılardan bazılarının doğrudan ifadelerine yer verilmiştir.

K1: "Insanları tanıma ve onlara şans verme noktasında çok faydası oldu. Aslında tüm bunlar beni başka biri yaptı sanki." 
K6: "Drama dersinden önce çok içe kapanıktım, kimseyle konuşmuyordum. Artık çekinmiyorum. Sadece kendime değil insanlara da güveniyorum."

K8: "Güvensiz bir insan, yok olmaya doğru bir yoldadır. Güvensizlikle başlayan adımlar önce başarısızlık, sonra yok olmayı getirir. Güvensizlik, tüm insanların gö̧ ettiği bir yerde kimsesiz kalmak gibidir. Güvensizlik hayatın anlamsızlaşması demektir. Bunlar bu yaptığımız uygulamalardan öğrendiklerim. Hep tekrar ediyorum. Etrafımdaki insanlara daha çok önem veriyorum, yalnızlaşmak istemiyorum. Kendimi fark etmeliyim. Ben değerliyim. Bunun için kendime güvenmeliyim."

K9: "Daha önce hiç konuşmadığım, selam bile vermediğim arkadaşlarımla konuşmak çok farklı hissettirdi. Herkes insana bir şey öğretiyor bence. Bu atölyelerden sonra bunu anladım ve bu çok değerli."

E2: "Fark ettim ki insanlarla sohbet etmek bile özgüveni arttırlyor. Atölyelerden sonra buna dikkat etmeye başladım. Otobüse bindiğimde selam veriyorum şoföre. O hiç bakmasa da cevap vermese de üzülmüyorum ben bana yakışanı yapıyorum diyorum."

E8: "Kendimi anlatabiliyorum, açıklayabiliyorum bazı şeyleri. Eskiden çok utangaçtım. Eskiden sırf kalabalık olur diye ortamlara girmiyordum. Kalabalık beni hep korkutuyordu. Şimdi sunum yaparken bile rahatım."

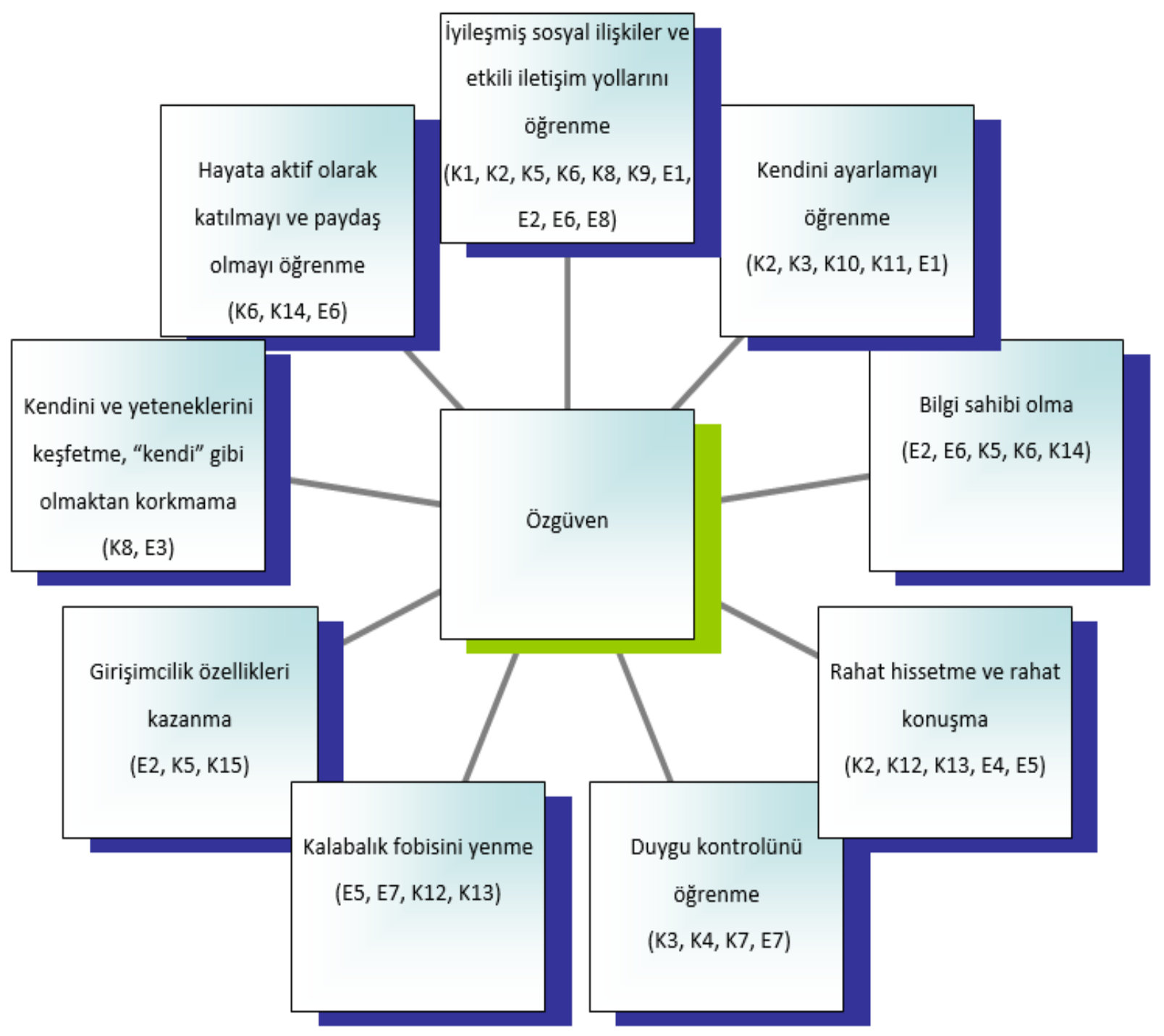

Şekil 3. Özgüvene ilişkin oluşturulan kategoriler

K2, K3, K10, K11 ve E1 kod adlı öğrenciler, kendini ayarlamayı öğrenmenin önemli olduğunu ve bu yolla kendilerine güven duyabildiklerini fark ettiklerini anlatmıştır. Aşağıda konuyla ilgili K3 kod adlı öğretmen adayının doğrudan ifadelerine yer verilmiştir.

K3: "Artık nerede nasıl davranacağım, daha netim bu konuda. Sınıfta gereksiz kasılmak, arkadaşlarla abartılı samimi olmak, ailemleyken sus pus olmak ya da çok sinirli bazen... Yani eskiden hep bunları yapıyordum. Insan kendine 
uygun, kişiliğine uygun tavrı göstermeli. Ben bunu bu atölyelerden sonra kazandım sanki. Nerede, nasıl davranacağımız önemli değil mi? Kendime daha çok inanıyorum artık."

$\mathrm{K} 2, \mathrm{~K} 12, \mathrm{~K} 13, \mathrm{E} 4, \mathrm{E} 5 \mathrm{kod}$ adlı öğrenciler, rahat hissetme ve rahat konuşmaya başlamanın kendilerine güven duymalarını sağladığını anlatmıştır. Bu yolla kendilerini daha iyi ifade edebildiklerini düşünen K2 ve K13 kod adlı öğrencilerin konuyla ilgili söyledikleri doğrudan ifadeleri şu şekildedir:

K2: "Kendimi daha iyi ifade edebildiğimi, rahatladığımı ve özgüvenimin arttığını fark ettim. Bu da sosyal becerilerimin gelişmesine ve iletişimimin güçlenmesine vesile oldu. En önemlisi insanları tanımam için bir yol oldu bu. Drama için iyi bir bireyi tanıma tekniği derken ne demek istediğinizi daha iyi anladım. Onları tanıdıkça rahat hissettim ve kendime güvenim arttı. Bulunduğum ortama göre kendimi kontrol edebilmemi sağladı."

K13: "Rahat olmak, sürekli gergin olmaktan çok daha iyi bir şeymiş. Okuduğum bölüm gereği bazı özelliklere sahip olmam gerekiyormuş. Bunları öğrendim. Elbette kendime güveniyorum, geleceğime güveniyorum. Bu çok önemli bir kazanım değil mi?"

K3, K4, K7, E7 kod adlı öğrenciler, duygu kontrolünü sağlayabildiklerini, aşırı heyecanı yenme ve gereksiz çekingenlikten kurtulmanın kendilerine güven duymalarını sağladığını anlatmıştır. Konuyla ilgili E7, şunları dile getirmiştir:

E7: "Eskiden çok utanırdım. Role girmek falan bana çok komik gelirdi. Şimdi rahatladım ve çekinmiyorum, konu anlatırken bile canlandırma yapıyorum."

E5, E7, K12 ve K13 kod adlı öğrenciler kalabalık fobisini yendikleri için kendilerine daha çok güvendiklerini dile getirmiştir. Konuyla ilgili E7'nin söyledikleri şu şekildedir:

E5: "Benim kalabalık korkum vardı. Ya şimdi orası çok kalabalık olur, gitmeyeyim diye evde oturduğumu biliyorum. Kalabalıklar korkunç gelmiyor artık. Insanlar utandırmıyor beni o kadar. Yani yine çekiniyorum ama eskisi kadar değil. Hayata katılmam gerektiğini fark ettim ve özgüvenim gelişti."

$\mathrm{E2}$, E6, K5, K6, K14 kod adlı öğrenciler bilginin, bilgi sahibi olmanın kendilerinde güven duygusu oluşturduğunu anlatmıştır. Onlara göre bilmek, anlamak, dağarcı̆̆ını genişletmek özgüven için olmazsa olmaz bir eylemdir. Konuyla ilgili K14'ün söyledikleri şu şekildedir:

K14: "Atölyelerden bir sürü şey öğrendim. Ünlü ressamların hikayeleri, farklı masallar, adını ilk kez duyduğum insanların sözleri... Bunlar bende güven oluşturdu. Dedim ki bundan sonra daha çok okumalıyım."

E2, K15 ve K5 kod adlı öğrenciler girişimcilik özellikleri kazandıkları için kendilerine güven duymaya başladıklarını anlatmıştır. Konuyla ilgili K5'in söyledikleri şu şekildedir:

K5: "Bir işe atılırken daha cesur davranmam gerekiyor. Girişimci biri hiç olmadım ben. Eksiğim buymuş dedim bu dersten sonra. Doğrusu kendime güveniyorum demiştim ilk başta ama çok eksiğim varmış, şimdi her şey daha farklı bana."

K6, K14 ve E6 kod adlı öğrenciler hayata aktif olarak katılmayı ve toplum yararına olabilecek bir işte paydaş olmayı öğrenmenin kendilerine güven duymalarını sağladığını anlatmıştır. Onlar bu yolla birey olma sorumluluğunu üstlenmişlerdir.

E6: "Bence hayata dair çok şey kattı. Hayata aktif katılmam gerektiğini fark ettim ve bu özgüvenimi geliştirdi. Ben bu toplumda bir kişi olarak işe yarıyor muyum? Öğretmen olarak işe yaramalıyım."

K8 ve E3 kod adlı öğretmenlerin kendine güven duymasını sağlayan en temel konu "kendini ve yeteneklerini keşfetme, kendi olmaktan korkmama" olmuştur. Öğretmen adayının konuyla ilgili söyledikleri şu şekildedir:

E3: "Yaptıklarımla kendime güven oluştu. Ben bunu yapabiliyormuşum dedim. Aslında sadece sınıftakileri değil, kendimi de tanıdım. Kendim olmak korkunç değil, ben de böyleyim diyorum."

\section{Özgür Düşünmeye ilişkin Bulgular}

Öğrencilere atölyelerden sonra kendilerinde özgür düşünmeyle ilgili değişiklik olup olmadığı sorulmuştur. Öğrencilerin 13'ü özgür düşünmeyle ilgili daha bilinçli olduklarını anlatmıştır. Kalan 10 katılımcı kendilerinde herhangi bir değişiklik gözlemleyemediğini ifade etmiştir. Katılımcıların konuyla ilgili düşünceleri, 6 kategoride toplanmıştır. Bu kategoriler Şekil 4'te gösterildiği gibidir. 


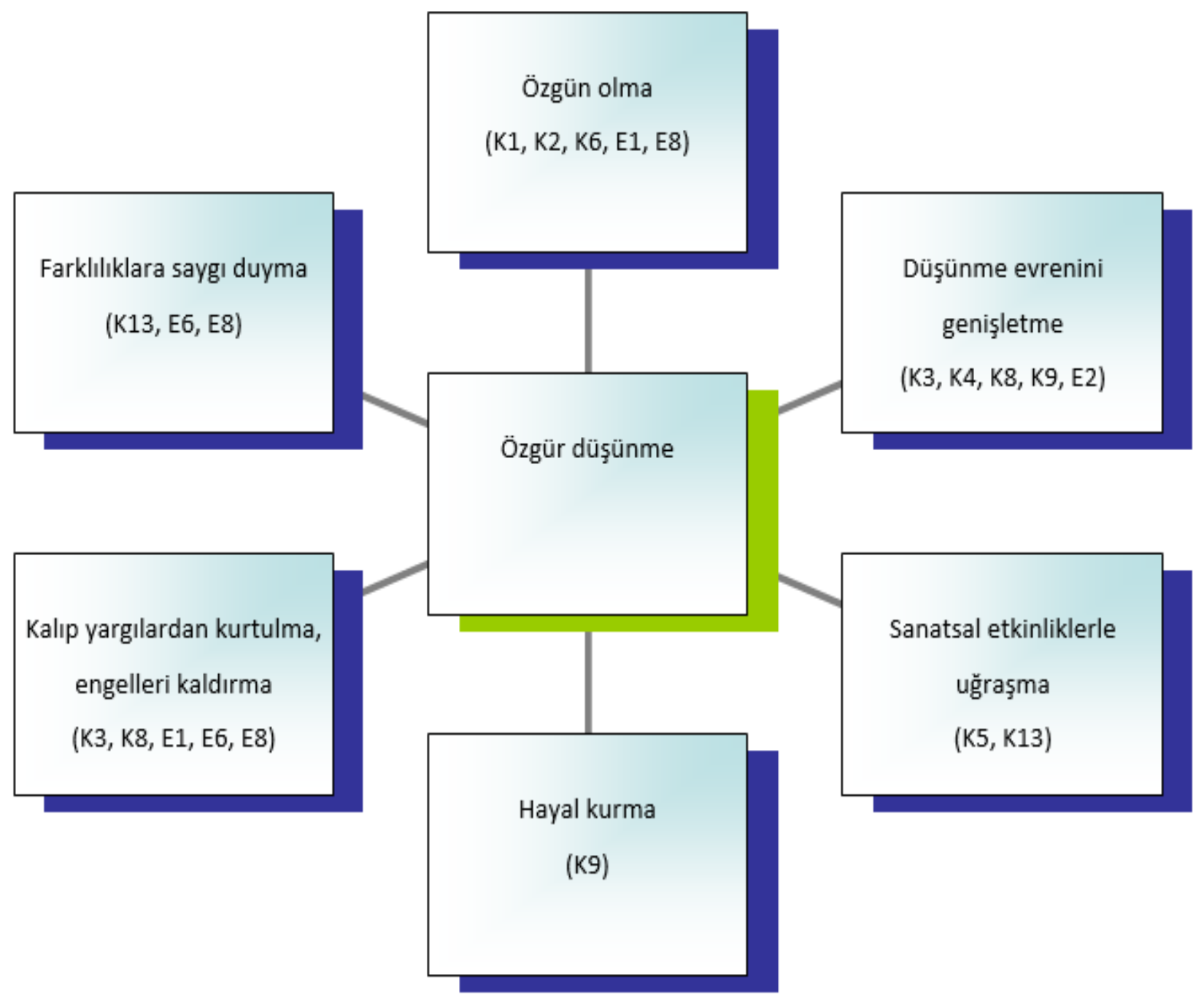

Şekil 4. Özgür düşünmeye ilişkin oluşturulan kategoriler

Şekil 4'ten de anlaşılacağı üzere K1, K2, K3, K4, K5, K6, K8, K9, K13, E1, E2, E6, E8 kod adlı 13 öğretmen adayı "farklılıklara saygı duymayı" öğrendiği, "özgün olmayı" deneyimlediği, "düşünme evrenini” genişlettiği, "hayal kurma” eylemi yaşadığı ve "kalıp düşüncelerden" kurtulup düşünmenin önündeki engelleri kaldırdığı için özgür düşünmesinin geliştiğini ifade etmiştir. Öğrencilerin birçoğu yapılan işlerin "sanata dair olduğunu" gözlemlemiş ve bunu çok faydalı bulduklarını anlatmıştır. K5 ve K13 kod adlı iki öğretmen adayı ise sanatla uğraşmanın kendilerine özgür düşünmek yolunda ufuklar açtı̆ı̆ını anlatmıştır.

K5: "Drama dersi bir sanat dersi niteliğindedir. Sanat zaten özgür düşünmeyi gerektirir. Kafamızdaki kalıplardan kurtardı bu atölyeler."

K3, K4, K8, K9 ve E2 kod adlı katılımcıların özgür düşünmesini sağlayan en temel konu "düşünme evrenini genişletme" olmuştur. Öğrenciler bu yolla beyin jimnastiği yaptıklarını, hayal gücünün sınırlarını zorladıklarını, yaratıcılıkla ilgili farkındalık kazandıklarını anlatmıştır. Bu katııımcılar zihni beslemenin önemli olduğunu, bu etkinliklere ilave olarak zihinsel olarak beslenmeleri gerektiğini düşünmektedir. Konuyla ilgili söylenenlerden bazıları şu şekildedir:

E2: "Bu ders sanki başka bir dünyaya götürüyor. İstediğin kadar saçmala, kimse bir şey demiyor. Bu anlamda sadece düşüncemde değil hareketlerimde de özgürmüşüm gibi... "

K9: "Tek bir materyalden neler çıkarttık. Eski bir gazeteden, anahtarlıktan, çöp dediğimiz şeylerden... Bunlar düşüncenin ucu bucağı olmadığını keşfettirdi. Beyin jimnastiği bir anlamda."

K1, K2, K6, E1 ve E8 kod adlı katılımcılar özgün olmanın ne denli önemli olduğunu deneyimlediklerini anlatmışlardır.

K1: "Aslında her fikir özelmiş, önemli değilse bile özelmiş. Çünkü özel olan birine aitmiş. Ben özgün olmanın bu derece değerli olduğunu hiç düşünmemiştim."

K6: "Kendi farkımı ortaya koymam gerektiğini düşünüyorum. Eskiden klasik olanı yapmaktan korkmazdım." 
E8: "Çünkü özgün olmanın ne kadar önemli olduğunu ve dramanın bunun için iyi bir araç olduğunu gördüm. içimdeki gizli cevheri çıkarttı drama."

K13, E6, E8 kod adlı öğrenciler özgür düşündüğü zaman farklılıklara saygı duyması gerektiğini anladığını ya da farklılıklara saygı duyan birinin daha özgür olabildiğini düşündüğünü ifade etmiştir.

K13: "Diğer bireylerin görüşlerine saygılı olmayı öğrendim. Ne saçma dediğim bir sürü fikir oldu ama sustum kırmamak için. Sonra başka şeyleri deneyimledim. Herkese saygılı olmalıyım ki benim fikrime de saygı duyulsun."

E6: "Kendi düşüncelerimizi başkalarınınkiyle sentezlediğimizde daha güzel şeyler çıkıyor. Bu sebeple herkesin fikrine saygı duymayı öğrendim. Bu beni daha özgün yaptı bence."

K3, K8, E1, E6, E8 adlı katılımcılar kalıp yargılardan kurtulmanın kendilerini rahatlattı̆ıını anlatmıştır. Onlar, bu yolla düşünmenin önündeki engellerin kalktığına inanmaktadırlar. Aşağıda sorulan soruya verilen cevaplardan doğrudan alıntılar yer almaktadır.

K3: "Bu söylediğim çok saçma dediğim zamanlar oldu. Sanki herkes ders sonuna kadar benim söylediğimi düşünüyormuş gibi utanırdım. Ama haftalar ilerledikçe saçma ya da değil konuşabilmeyi öğrendim. Kafamdaki ön yargılardan kurtulduğum an özgür olacağımı anladım."

\section{E1: "Prangalarla yaşıyoruz. Atölyelerin birinde öyle demişti birisi."}

K9 kod isimli bir öğrenci ise drama atölyeleri yoluyla hayal kurmayı öğrendiğini anlatmıştır. Ona göre hayaller, insanı özgün olmaya ve özgür düşünmeye götürebilir. Bir başka ifadeyle hayal kurmak, özgünlük için gerekli olduğu gibi sadece hayal kurabilen insanlar özgürdür.

K7, K10, K11, K12, K14, K15, E3, E4, E5, E7 kod isimli öğrenciler, kendilerinde özgür düşünmenin geliştiğine dair herhangi bir gözlemleri olmadığııı, özgür düşünmenin gelişiminin birkaç haftalık uygulamanın yapıldığı dar bir alana sıkıştırılamayacağını anlatmışlardır. Bu öğrencilerden $\mathrm{K} 15$, kendisinde özgür düşünmek değil ama düşüncelerini özgürce ifade etmek eyleminin geliştiğinden söz etmiştir. Bir öğretmen adayı da özgür düşünme kavramına itiraz etmiş, düşüncenin kendisinin zaten özgür olduğunu, ona ayrıca "özgür" sıfatını eklemenin manasız olduğunu dile getirmiştir. Aşağıda söylenenlerden alıntılar yer almaktadır.

K15: "Bu atölyeler bana özgür düşünme anlamında bir şey katmadı ama düşündüklerimi dile getirme özgürlüğü konusunda bir değişikliğe sebep oldu."

K14: "Birkaç uygulama yapınca keşke gelişse özgür düşünme. Ama öyle değil. Bu bir düzen ve sistem içinde gelişebilir."

E5: "Özgür düşünme diye bir şey yoktur bence. Düşünme zaten özgürdür. Bu anlamda bir değişiklik yok bende."

\section{Sonuç ve Tartışma}

Bulgulardan hareketle yaratıcı drama yöntemiyle verilen eğitimin, katılımcılarda değerlerin bu yöntemle kazandırılabilir olduğuna ilişkin bir fikir oluşturduğu gözlenmiştir. "Yaratıcı dramanın kendisinin, özel olarak özgüven ve özgür düşünme konuları işlenmese de özgüven ve yaratıcılığı geliştirmek için oldukça etkili olduğu; atölye konusu özel olarak özgüven ve özgür düşünme olduğunda ise bu etkinin daha da arttığı" görüşü hakim olmuştur. Öğrenciler atölyelerden sonra, kendilerine güvendiklerinde neleri başarabileceklerine dair inançlarının olumlu yönde değiştiğini vurgulamış, böyle soyut kavramlarla çalışmak zor olsa da atölyelerden keyif aldıklarını ifade etmişlerdir. Özgür düşünmeyi ifade özgürlüğü kavramıyla karıştıran ya da siyasi bir olguymuş gibi algılayan katılımcılar onun gerçekte ne olduğuyla ilgili bilgi sahibi olmuş ve bundan sonra kendilerini bu yolda geliştirmek için çabalayacaklarını ifade etmişlerdir. Katılımcılar ayrıca herkesin diğerleriyle aynı olmaya adeta zorlandığı bir çevrede, kendin olarak kalabilmenin zor ama çok anlamlı olduğunu fark ettiklerini belirtmişlerdir. Çalışma sonunda yaratıcı dramanın, özgür düşünme ve özgüven değerlerinin kazandırılmasında kullanılabilecek bir yöntem olduğu görülmüştür.

Öğrenciler kendi düşüncelerini özgüvenli bir şekilde ifade edemedikleri için diğer insanların düşünceleri karşısında çok hassas olduklarının farkına vardıklarını ifade etmişler; başkalarına karşı besledikleri güvenin, kendilerine olan güvenle ilişkili olduğunu hissetmişlerdir. 


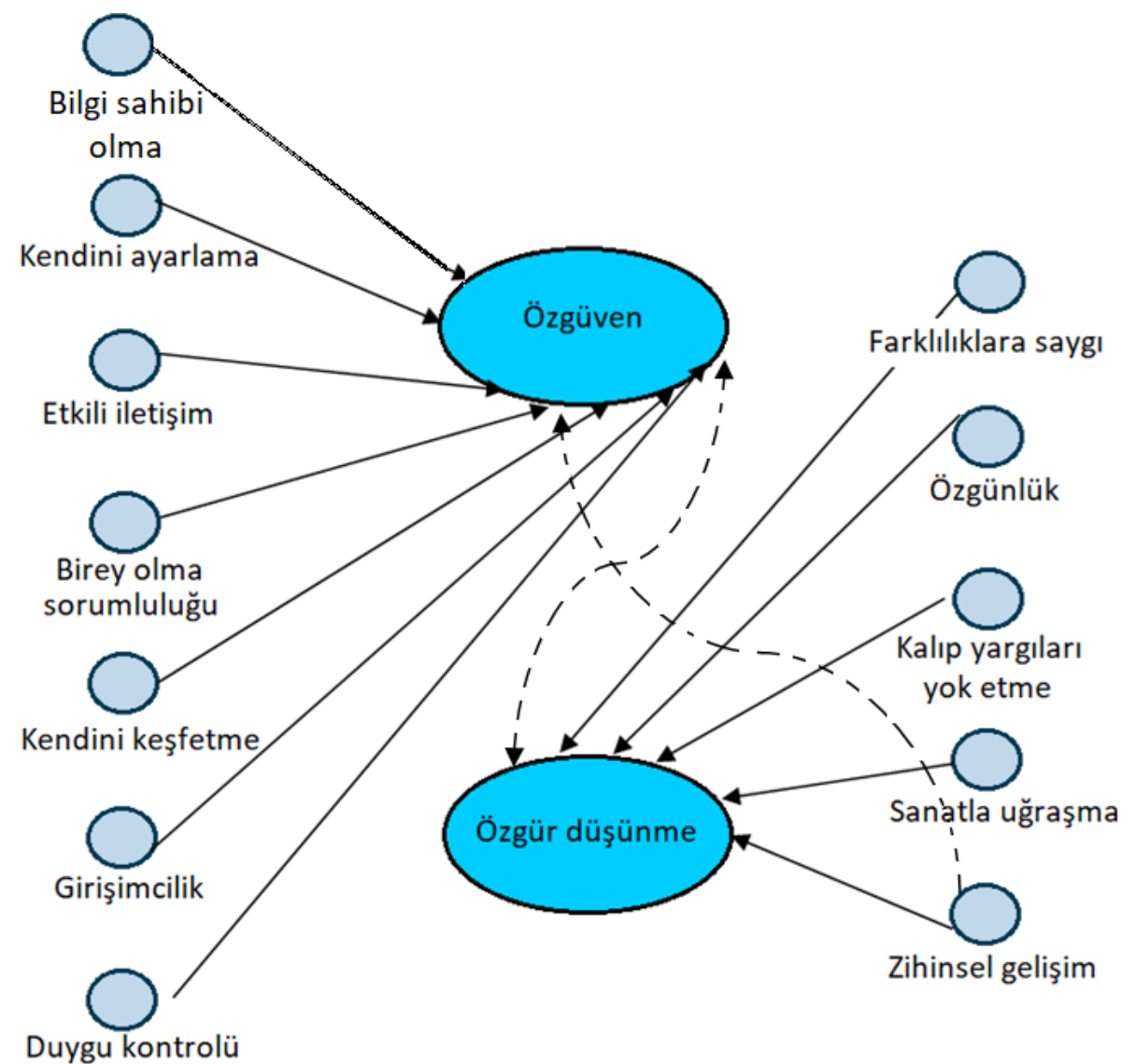

Şekil 5. Özgüven ve özgür düşünmenin ilişkili olduğu kategorilerin toplu gösterimi

Şekil 5'te görüldüğü gibi özgüven "bilgi sahibi olma, kendini ayarlama, etkili iletişim, birey olma sorumluluğu, kendini keşfetme, girişimcilik ve duygu kontrolü" kavramlarıyla ilişkili bulunmuştur. Öğrencilere göre bilgi sahibi olma ya da yeni bilgiler elde etme kendine güven için önemlidir. Bulgular ışığında öğrencilerin kendine güven duymaları için kendilerini keşfetmeleri gerektiğini anladıkları görülmektedir. Yaratııı dramanın hem kendini hem sosyal bağlamı keşfetmek noktasındaki olumlu etkisi atölyeler boyunca etkili olmuştur. Katılımcılar, kendine güvenmenin, başkalarına da güvenmeyi beraberinde getirdiğini ya da başkalarına güvenebilmek için ilk önce kendine güven duymak gerektiğini öğrendiklerini ifade etmişlerdir.

Bulgulara göre özgür düşünme, "farklılıklara saygı, özgünlük, kalıp yargılardan kurtulma, sanat ve zihinsel gelişim" ile ilişkili bulunmuştur. Şekil 5'te zihinsel gelişim, çizgili okla özgüvene götürülmüştür. Bu şekilde bir çizim yapmada, öğrencilerin özgür düşünmelerini doğrudan etkilediğine inandıkları zihinsel gelişimin, dolaylı olarak da özgüvenlerini geliştirdiğine dair ifadeleri etkili olmuştur. Öğrenciler tarafından özgüvenle ilişkilendirilen "bilgi sahibi olmak", zihinsel gelişim için önemli olmakla birlikte bir bütün olarak düşünüldüğünde yeterli değildir. Çünkü zihinsel gelişim, bilgi sahibi olmanın ötesinde üst düzey birtakım becerileri de gerektirmektedir. Bu sebeple bilgi sahibi olmak ve zihinsel gelişim ayrı kategoriler olarak düşünülmüştür.

Öğrencilerin kendilerine güvenen, sistemli düşünebilen, girişimci, plânlı çalışma alışkanlığına ve eleştirel bakış açısına sahip, estetik duyguları ve yaratıcılıkları gelişmiş bireyler olmalarını sağlamanın önemi göz önünde bulundurulduğunda "bağımsız ve özgür düşünme" ile "özgüven" değerleri eğitimciler ve öğrenciler için çok önemli iki kavramdır. Bu çalışmanın bulgularına göre öğrenciler bu iki kavramı birbiriyle ilişkilendirmektedir. Şekil 5'te özgüven ve özgür düşünmenin çizgili okla birleştirilmesi bu ilişkiye dikkat çekmektedir.

Öğrencilerin özgüvenlerini artırmak için olumlu ve olumsuz yönlerini tanıma, kendilerini olduğu gibi kabul etme düşünce biçiminin geliştirilmesine yönelik hazırlanan drama atölyeleri katılımcılarda olumlu etkiler bırakmıştır. Bu sonuçla benzer bir sonuç Danielson'un (1992) çalışmasında da elde edilmiştir. "10. sınıf öğrencilerinin sosyalleşmesinde drama temelli öğretimin değerlendirilmesi" adlı çalışmada yaratıcı dramanın sosyal becerilerin öğretilmesinde etkili olduğunu ve öğrencilerde sosyal becerilere karşı olumlu tutum geliştirdiği tespit edilmiştir. Ayrıca Kara ve Çam da (2007) yaptıkları çalışmada drama yönteminin, gelişim ve öğrenme dersinde öğrencilerin grupla bir işi yapma ve yürütme becerileri ile kendini kontrol etme becerileri üzerinde etkili olduğu sonucunu bulmuşlardır. 
Ancak bazı çalışmalarda bu çalışmanın tersi sonuçlar dikkati çekmektedir. Uşaklı (2006), drama temelli grup rehberliğinin, benlik saygısının artmasında anlamlı düzeyde etkili olmadığı sonucunu bulmuştur. Sert (2003), benzer şekilde atılganlık eğitiminin ilkokul beşinci sınıf öğrencilerinin atılganlık ve benlik saygısı seviyelerine olan etkisini incelemiştir. Bu araştırmanın sonuçlarına göre, atılganlık eğitiminden sonra kontrol grubunun benlik saygısı puanlarında bir değişme olmamıştır. Bu çalışmanın sonuçlarına benzemeyen bu gibi diğer araştırmaların sonuçlarından hareketle, özgüven ve özgür düşünmeye ilişkin atölyelerden sonra oluşan olumlu havanın sadece kullanılan yöntemle ilişkili olmayabileceği, katılımcı özellikleri, grup dinamiği, drama liderinin tutum ve davranışlarının da sonucu etkilemiş olabileceği yorumu yapılabilir. Bu bağlamda meseleye çok boyutlu yaklaşıp bu türlü değerleri kazandırmak için sadece kullanılan yöntemlerin değil, ilgili koşulların tamamının iyileştirilmesinin önemi ve gerekliliği ortaya çıkmaktadır.

\section{5. Öneriler}

Özerk karar verebilen, yeterlik duygusuna sahip ve sosyal olarak aidiyet hisseden bireylerin, özgün ve yaratıcı fikirlere en yakın kişiler olduğu söylenebilir. İnsanları özgün kılan özellikleri gün yüzüne çıkarmak ya da öz belirleme kuramı kapsamında benlik bilinci oluşturmak, geleceğin mimarı öğretmenler için özellikle önemli görülmektedir. Öğretmenlerin zihinsel özerkliği, öğrencilerin özerkliği kadar önemlidir. Çünkü ancak kendisi özgün olabilen öğretmenler, özerklik, yeterlik ve aidiyet duygusu gelişmiş çocuklar yetiştirme konusunda daha etkin olabilir. Bu bağlamda öğrenciler ve öğretmenler için bu türlü eğitimler verilmelidir.

Özgüven, özgür düşünme, özsaygı, özerklik, yeterlik gibi psikolojik temeli olan kavramlar için uygun yaklaşımlar tespit edilmeli ve kazandırılması için en etkili şartlarda uygulanmalıdır. Böyle değer ya da psikolojik yapılar, özellikle çevreyle etkileşim yoluyla denenerek ve gözlemlenerek kazanılmakla birlikte metodolojik ve kasıtlı bir biçimde öğretilmelidir (Bishop, 1993). Demokratik toplumlarda eğitim kurumları; sadece bilişsel amaçlara ulaşmak için değil, aynı zamanda insanı insan yapan ölçütlerin, öğrencilere verildiği bir yapı olma anlayışına sahip olmak için de çaba sarf etmelidir.

Eğer, sorgulayabilen, olaylara eleştirel yaklaşabilen, geniş bakış açısına sahip, yeni ve özgün bilgileri kullanabilen, yaratıcılık özellikleri açığa çıkarılmış bireyler yetiştirilmesi günümüzün ihtiyacıysa, bu amaçla insan yetiştirmenin en önemli gerekliliğinin öğretmenlerin söz konusu niteliklere sahip olması gerekmektedir. Bu gereklilik ve inançla Eğitim Fakültelerindeki öğretmen adaylarına bu türlü eğitimler verilmesi önerilmektedir.

\section{Kaynakça}

Baldwin, P. (2009). School Improvement Through Drama, A creative whole class, whole school approach. London: Network Continuum Education.

Beverly, J. (1993). Teacher As Researcher. ERIC Clearing House on Teacher Education, Washington DC, No: 355205. https://files.eric.ed.gov/fulltext/ED355205.pdf

Bishop, C. D. (1993). Report of The Task Force on Values in Education For The State Of Arizona. Arizona Department of Education (ERIC Document Reproduction Service No: ED 386270).

Danielson, T. R. (1992). Evaluating the Ability of Drama-Based Instruction to Influence the Socialization of Tenth Grade English Students Labeled as "Low Ability." (Report No. CS-508-455). (ERIC Reproduction Service No. ED367000)

Deci, E. L. \& Ryan R. M. (1985). Intrinsic Motivation and Self-Determination in Human Behavior. New York: Plenum Press.

Deci, E. L., \& Ryan, R. M. (2000). The "What" and "Why" of Goal Pursuits: Human Needs and the Self-Determination of Behavior. Psychological Inquiry, 11, s. 227-268.

Devries, R. (1997). Piaget's Social Theory. Educational Researcher, 26, 4-18.

Devries, R. (1999) Implications of Piaget's Constructivist Theory for Character Education, Action in Teacher Education, 20:4, 39-47.

Guli, L. A. (2004). The Effects of Creative Drama-Based Intervention for Children with Deficits in Social Perception. The University of Texas at Austin, Texas.

Gutek, L. G. (2001). Eğitime Felsefi ve Ideolojik Yaklaşımlar. (Çeviren: Nesrin Kale), Ankara: Ütopya Yayınları.

Kamii, C. \& Ewing, J. K. (1996) Basing Teaching on Piaget's Constructivism, Childhood Education, 72:5, 260-264. 
Kara, Y. ve Çam, F. (2007). Yaratııı Drama Yönteminin Bazı Sosyal Becerilerin Kazandırılmasına Etkisi. Hacettepe Üniversitesi Eğitim Fakültesi Dergisi, 32 (32): 145-155.

O'Loughlin, M. 1992. Rethinking Science Education: Beyond Piagetian Constructivism Toward A Sociocultural Model Of Teaching And Learning, Journal of Research and Science Teaching. 29(8): 791-820.

O'Brien, R. (2001). An Overview of the Methodological Approach of Action Resaerch. (Online). https://youthsextion.files.wordpress.com/2011/04/14action-research.pdf

Piaget, J. Six Psychological Studies. New York: Vintage Books, 1967.

Rokeach, M. (1973). The Nature of Human Values. New York: The Free Press. https://www.cambridge.org/core/journals/american-political-science-review/article/nature-of-humanvalues-by-milton-rokeach-new-york-the-free-press-1973-pp-4381395/6B4C53A7BA178CB3DE3197BA08B5E383

Schiefele, U. (2001). The Role of Interest in Motivation And Learning, In J. M. Collis \& S. Messick (Eds.). Intelligence and personality: Bridging the gap in theory and measurement Mahwah, NJ: Erlbaum.

Schwartz, S. H. (1992). Universals in the Content And Structure of Values: Theory And Empirical Tests in 20 Countries. In M. Zanna (Ed.), Advances in Experimental Social Psychology (Vol. 25, pp. 1-65). New York: Academic Press. http://dx.doi.org/10.1016/S0065-2601(08)60281-6

Schwartz, S. H. (1994). Are There Universal Aspects in The Content and Structure of Values? Journal of Social Issues, 50, 19-45. http://dx.doi.org/10.1111/j.1540- 4560.1994.tb01196.x.

Schwartz, S. H. (2012). An Overview of the Schwartz Theory of Basic Values. Online Readings in Psychology and Culture, 2(1).

Sert, A. G. (2003). The Effect of an Assertiveness Training on the Assertiveness and Self Esteem level of 5th Grade Children. Unpublished Master Dissertation, Middle East Technical University.

Uşaklı, H. (2006). Drama Temelli Grup Rehberliğinin İlköğretim 5. Sınıf Öğrencilerinin Arkadaşlık İlişkileri, Atılganlık Düzeyleri ve Benlik Saygısına Etkisi (Yayımlanmamış doktora tezi). Dokuz Eylül Üniversitesi Eğitim Bilimleri Enstitüsü, İzmir.

Wadsworth, B. J. (2015). Piaget nin Duyuşsal ve Bilişsel Gelişim Kuramı. (Z. Selçuk, M. Kandemir, A. Kaşkaya, M. Palancı, Çev.). PegemA Yayıncılık, Ankara

Yıldııım, A. ve Şimşek, H. (2000). Sosyal Bilimlerde Nitel Araştırma Yöntemleri (Gözden geçirilmiş 2. baskı). Ankara: Seçkin Yayıncılık. 
Ek 1: Üçüncü Özgüven Uygulamasında Kullanılan Drama Atölyesi ${ }^{3}$

\begin{tabular}{|l|l|}
\hline Konu & Özgüven \\
\hline Süre & 90 dakika \\
\hline Grup & Öğrenciler (23 kişi) \\
\hline Mekân & Eğitim Fakültesi Drama salonu \\
\hline Teknik & Rol oynama, donuk imge \\
\hline Araç-Gereç & $\begin{array}{l}\text { Kalem, çeşitli boyutlarda resim kağıtları, boya kalemleri, Kitaro'nun "Silk Road” isimli } \\
\text { parçası, “Kendine Güvenen Kurbağa” isimli hikaye, çeşitli özlü sözler }\end{array}$ \\
\hline Kazanımlar & $\begin{array}{l}\text { Özgüven duymanın ne kadar önemli olduğunu kavrar. } \\
\text { Güçlü ve güçsüz yanlarını ifade eder. }\end{array}$ \\
\hline
\end{tabular}

\section{A. Hazırlık/Isınma}

\section{Etkinlik: Kendime İnanmadığımın Resmidir!}

Lider bir yandan öğrencilerden mekanda serbestçe yürümelerini isterken bir yandan da şu cümleleri kurar: "Çok güçsüzsünüz. Yalnız ve amaçsız yürüyorsunuz. Kendinize inanmıyorsunuz. Kendi içinizde hiçbir değeriniz olmadığı gibi kimsenin gözünde de bir değeriniz yok...". Bu sırada mekanda kısık perdeden Kitaro'nun "Silk Road" isimli parçası dinletilmektedir. Lider, katılımcılardan cümlelerinin sonunda donmalarını ve bedenleriyle hissettikleri durumu yansıtan bir donuk imge oluşturmalarını ister. Katılımcılar sırayla mekanda gezer ve donuk imgeleri inceler. İnceleme sonunda tekrar donuk imge formunu alır. Öğretmen öğrencilere aşağıdaki soruları yöneltir.

Insanlar mutlu muydu?

Kendinizi nasıl hissettiniz?

Donuk imgelerle ne anlatıyordunuz?

\section{Etkinlik: Heykel Sergisi}

Lider, katılımcılara hep birlikte bir heykel sergisine gideceklerini ve sergideki heykellere, hissettirdiklerinden hareketle isimler vereceklerini söyler. Illk etkinlikteki donuk imgelerin bir heykel sergisi formatında sıralanması sağlanır. Sırayla her katııımcı beden formatını kısa süreliğine bozup heykellerden birine gider ve ona en yakışan ismi kağıda yazıp görünmeyecek şekilde yakasına takar. Gruptaki herkes bir heykele isim verdiğinde etkinlik tamamlanır. Bu etkinlikte heykellere verilen ilk isimlerin görülmesi öğrencilerin merakını canlı tutmak için engellenir. Yaka kartlarının görünmeyecek şekilde ters çevrilmesi "Değerlendirme" aşamasında gerçekleştirilecek donuk imge etkinliği için önemlidir.

\section{Etkinlik: Parazit Oyunu}

Grup üç eşit sayıda gruba ayrıır (Öğrenciler 1, 2, 3 diye sayar. 1'ler, 2'ler ve 3'ler birbirini bulur.) 1'ler ve 3'ler karşılıklı dizilirler. Bu arada 2'ler de ortada dizilir.

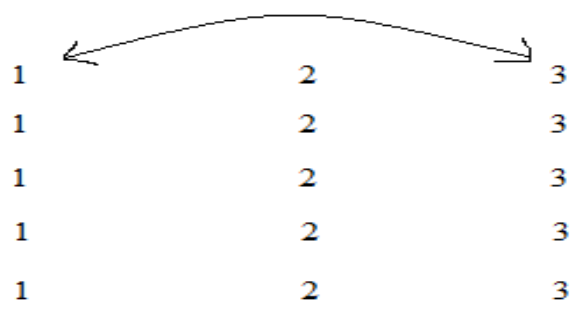

Şekil 1. Öğrencilerin duruş pozisyonu

\footnotetext{
${ }^{3}$ Bu çalışmanın amacı için toplamda 6 "özgüven ve özgür düşünme" atölyesi uygulanmış olup Ek 1'de sadece bir tanesi örnek olması açısından paylaşılmıştır.
} 
Öğretmen herkesin tam karşısında duran kişinin eşi olduğunu söyler ve 1'lerin her birine elindeki kâğıtta yazılı olan bir cümleyi sessizce söyler. 1'lerin hedefi, öğretmenin verdiği bu cümleleri karşıda 3'ler sırasında duran eşlere yüksek sesle hatta bağırarak söyleyerek 1 dakika sürede iletmektir. Bu sırada 2'lerin görevi ise 1'ler ve 3'ler arasındaki iletişime engel olmak için gürültü yaparak parazit olmaktır. 1 dakikalık tur tamamlanınca öğretmen $3^{\prime}$ lerin yanına gelip ne duyduğunu sorar. Doğru duyulamamışsa cümlenin doğrusu 1'ler sırasındaki eşe sorulur. Tur tüm öğrenciler 1, 2 ve 3 yani, "gönderici, parazit ve alıcı" olana kadar 3 seri devam ettirilir.

\section{Tablo 1. Etkinlik için örnek özlü sözler}

- Kendini okyanusta bir damla sanma. Bir damlanın içinde kocaman bir okyanussun. (Mevlana)

- Şampiyon olabilmek için, hiç kimse size inanmadığında kendinize inanmanız gerekir. (Ray Robinson)

- Siz kendinize inanın, başkaları size inanacaktır. (Tacitus)

- Inanmaya, sevmeye ve güvenmeye kendinden başla. (Tayfun Topaloğlu)

- Sen eşsiz birisi olarak doğdun, bir kopya olarak ölme. (John Mason)

- Kendine güvenen herkes dünyayı yönetebilir. (Voltaire)

- Kendine güvenin yoksa bütün yollar kapanacaktır önünde. (Alain)

- Hiç bir merdiven olmasa bile, kendi başının üstünde tırmanmayı öğrenmelisin. (Friedrich Nietzsche)

- Başarıya giden yol, içinizdeki hazineyi keşfetmekle başlar. (S. Clower)

- Kendinize inanın, güzel şeyler olmaya başlar. (David J. Schwartz)

- Kendini fethedebilen kişiye, karşı koyabilecek pek az şey vardır. XIV. Louis

- Yüreğinin ve beyninin ateşine güvenmeyenler, kalıcı başarılara imza atamazlar. (Friedrich Nietzsche)

- Kendine güven; aklın, kesin bir inanç ve güvenle, büyük ve gurur verici işlerde kullanılmasıdır. (Cicero)

- Yapabileceğinizi düşünüyorsanız yapabilirsiniz, yapamayacağınızı düşünüyorsanız, haklısınız. (M. K. Ash)

- Insanlar bize, bizim kendimize inandığımız kadar inanırlar. (Karl Gutzkow)

\section{B. CANLANDIRMA}

\section{Etkinlik:}

Öğretmen tüm sınıfa aşağıdaki hikayeyi okur ve daha sonra 4 grup oluşturur ve iki kümenin özgüvenle ilgili olumlu bir durumu, diğer ikisinin olumsuz bir durumu anlatan birer hikayeyi 2 dakikalık kısa bir filmle canlandırmalarını ister. Hazırlanmaları ve rol dağıtımı için kümelere 10 dakikalık süre verilir. Canlandırmalar sergilenir.

\begin{tabular}{|c|}
\hline Kendine Güvenen Kurbağa \\
\hline 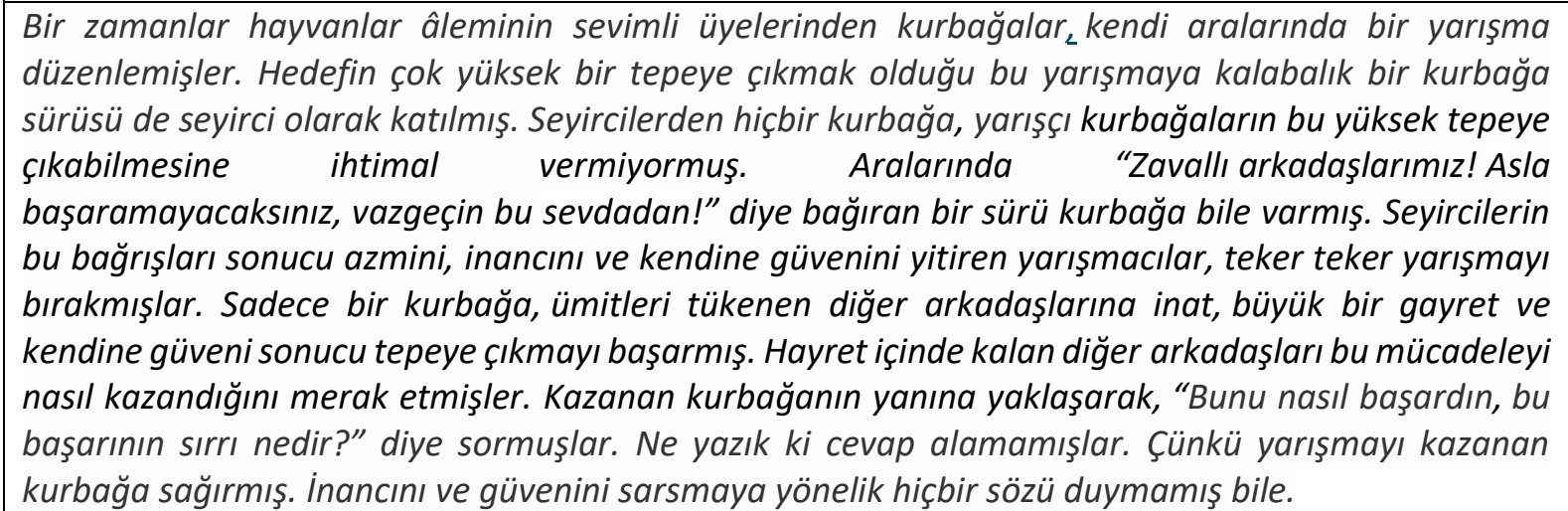 \\
\hline
\end{tabular}




\section{Ara Değerlendirme}

Öğretmen sergilenen canlandırmalar üzerinden öğrencilere özgüven değeriyle ilgili şu soruları yöneltir:

- Neler hissettiniz? Özgüven hayatta neleri değiştirir?

- Özgüven kişiler arası ilişkileri nasıl etkiler?

- Özgüvenle ilgili ne gibi yaşantılarınız var?

\section{DEĞERLENDIRME}

\section{Etkinlik: Broşür ve Şarkı Hazırlama}

Öğretmen sınıfı 4 gruba ayııır. Gruplardan ikisinden ellerindeki boya kalemleri ve resim kâğıtlarını kullanarak “özgüven” $i$ anlatan broşürler hazırlamalarını ister. Öğrencilere broşürlerde isterlerse parazit oyunundaki cümleleri de slogan cümlesi olarak kullanabilecekleri söylenir. Diğer iki grubun görevi özgüvenle ilgili şarkı yazmak ve birlikte söylemektir. Hazırlanmaları için her gruba 10 dakikalık süre verilir. Hazırlanan broşürler uygun yerlere asılır ve lider gruplardan bütün broşürleri dikkatle incelemelerini ister. Şarkılar ilk önce onu hazırlayan grup daha sonra tüm sınıf tarafından söylenir.

\section{Etkinlik: Güven Veren Donuk İmgeler}

Lider gruba 5. Etkinlik için hazırlanan broşürler ve dinledikleri şarkılardan hareketle bedenlerine bir form verip donmalarını söyler. Bu sırada onlara yüksek sesle şu cümleleri tekrar eder:

"Kendine güvenen herkes dünyayı yönetebilir. (Voltaire)", "Ben savaştığım adamı yenmeye çalışmam; onun özgüvenini yenmeye çalışırım. Şüpheyle uğraşan bir zihin zafere odaklanamaz. Birbirine eşit iki adam, ancak özgüvenleri birbirine eşitse, gerçekten eşit sayılırlar. (Arthur Golden)".

Gruptaki herkes, donmuş durumda bedeniyle bir şeyler anlatmaya çalışıyordur. Lider donuk imgeler arasında dolaşır ve sırayla bir el hareketiyle çözdüğü donuk imgelere diğer arkadaşlarını incelemelerini ve yakalarında ters şekilde takılı duran kartların boş olan tarafına o heykelle ilgili ona en yakışacağını düşündükleri ismi vermelerini söyler.

Ara değerlendirme: Heykellere niçin o isimlerin verildiğiyle ilgili konuşulduktan sonra lider gruba aşağıdaki soruları sorar.

- Donuk imgelerle ne anlatıyordunuz?

- Heykellere verdiğiniz ilk isimlerle bu etkinlikte verdiğiniz isimler arasında ne gibi farklılıklar var? Sizce neden?

- Özgüven yoksa neler olabilir?

\section{Etkinlik: Güçlü ve Güçsüz Yanlarım}

Lider her katılımcıya boş bir kâğıt verip bir insan yüzü çizmelerini ve onu dikey olarak ikiye katlamalarını söyler. Çizilen insan yüzünün bir tarafına kendilerini güçlü hissettikleri özellikleri, diğer yüzüne de zayıf olduklarını düşündükleri özelliklerini yazmalarını ister. Katılımcılara düşünmeleri ve kendilerini doğru değerlendirmeleri için verilen süre sonunda herkes çizdiği resme yazdıklarıyla ilgili konuşturulur. 


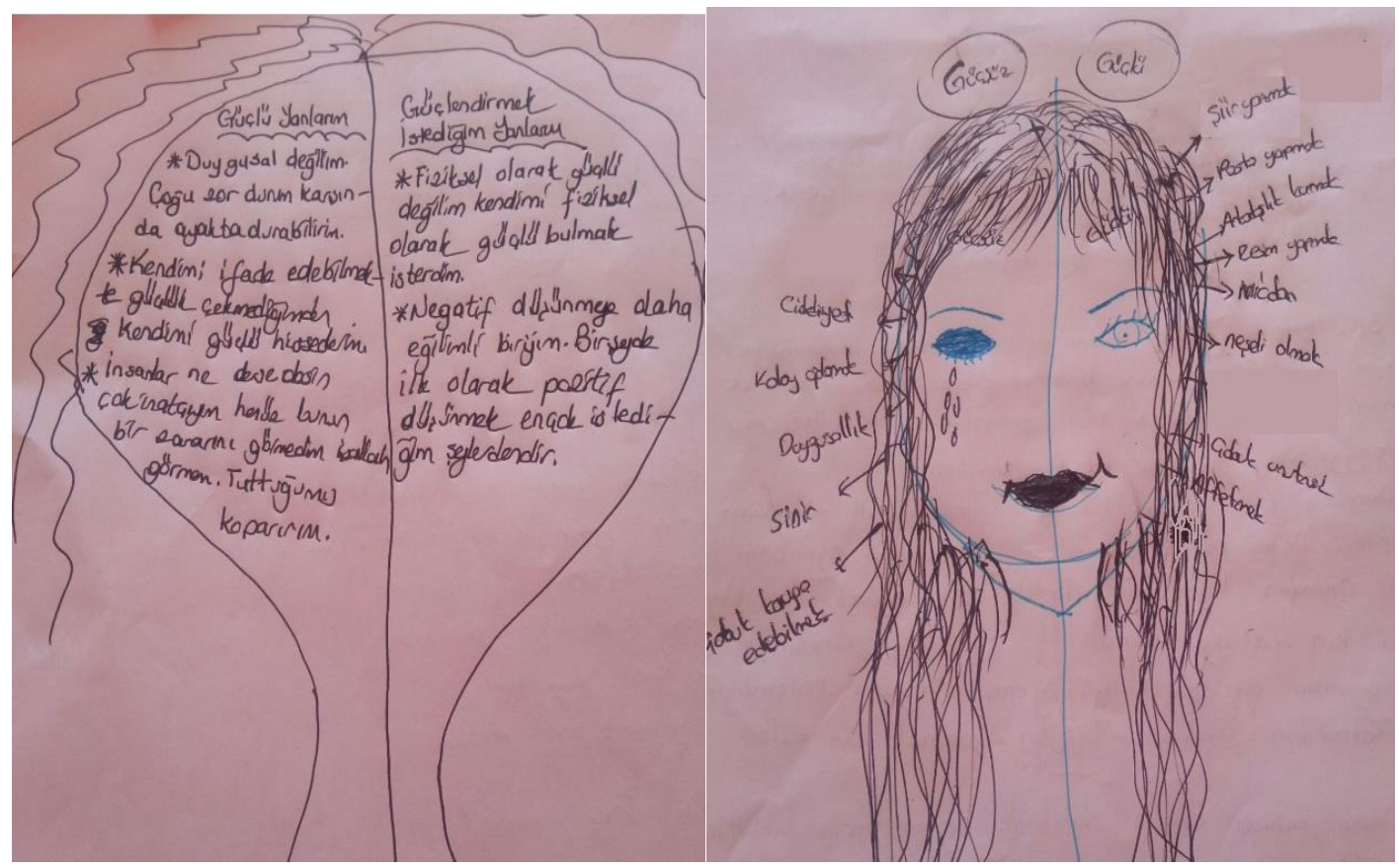

Şekil 2. "Gü̈çlü ve güçsüz yanlarım" etkinliği için hazırlanan bazı materyaller

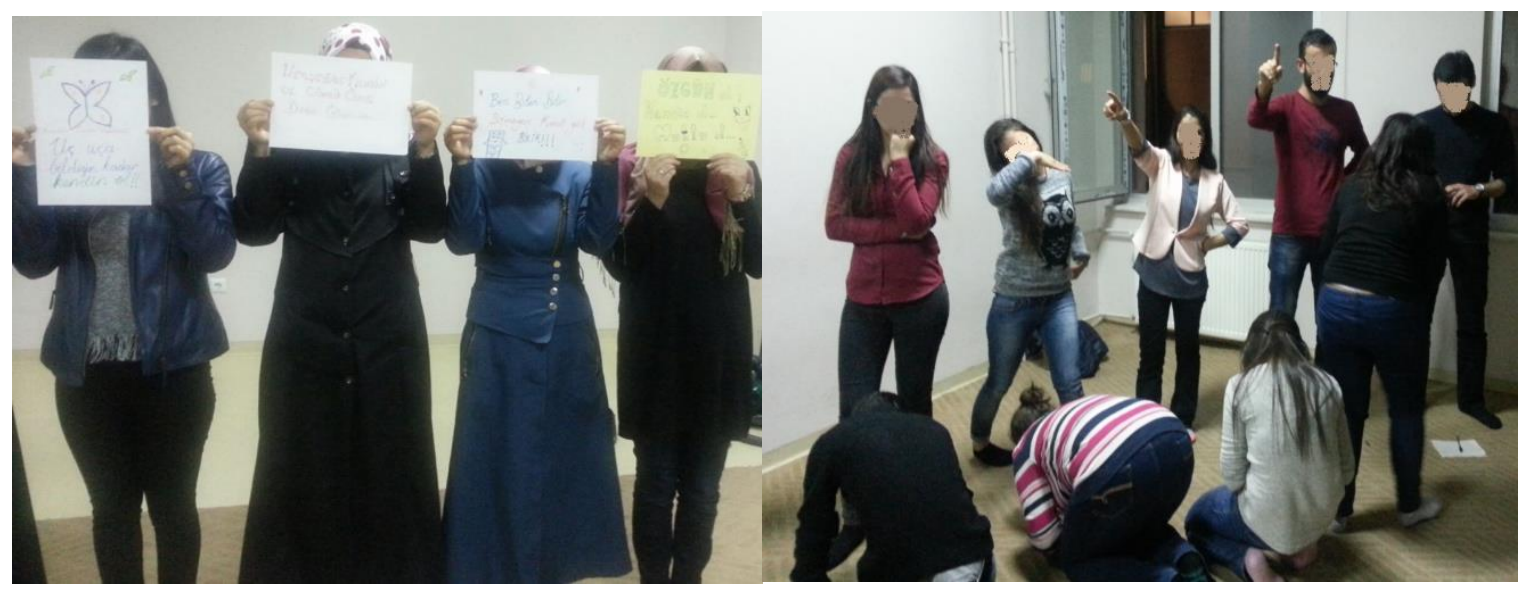

Şekil 3. Uygulama sırasında çekilen bazı fotoğraflar 